\title{
$\nabla$ IJCRR \\ Two New Cladosporium Species from Murshidabad District, West Bengal, India
}

Associate Professor, Department of Botany, Krishnath College, Berhampore, Murshidabad-742101, West Bengal, India.

\section{ABSTRACT}

Introduction: Cladosporium is a member of dematiaceous hyphomycetes which is characterized and easily recognised by its unique structure of the conidiogenous loci and conidial hila. Despite being imperfect in forms, they are the most versatile organisms in nature. While working on dematiaceous hyphomycetes from Murshidabad district, two specimens of Cladosporium had been collected which on critical examination characterised as two new species.

Methods: The infected leaves with distinct symptoms were collected and dried to make herbarium specimens. The microscope slides were prepared in lacto-phenol cotton blue mixtures of the recognised species. The fungi, treated here were studied in their natural habitat on the leaves of Clitoria terrnatea and Hibiscus mutabilis.

Results and Discussion: Two new species of Cladosporium viz. Cladosporium clitoriae Haldar and Cladosporium murshidabadense Haldar on Clitoria ternatea Land Hibiscus mutabilis L. respectively had been collected, figured and described in the present communication with notes on their phylogeny and ecology.

Key Words: Anamorphic, Hyphomycetes, Taxonomy, sp.nov

\section{INTRODUCTION}

The genus Cladosporium, a well documented fungus and was established by Link in the year 1815 with Cladosporium herbarum (Pers: Fr.) Link ex S.F. Gray is the type species. It had been named as "Klados" means a branch, hence branched spore chains. The taxonomic position of the genus Cladosporium is almost accepted as being a member of the form family Cladosporiaceae under the order Hyphomycetes of the form class Deuteromycetes. The genus Cladosporium is well characterized and easily recognised by its unique structure of the conidiogenous loci and conidial hila which classified as coronate, i.e., composed of a central convex dome surrounded by a raised periclinal rim. Cladosporoid are common and worldwide distribution and it is one of the largest, most heterogeneous genera of hyphomycetes, comprising more than 772 names i.e., valid, invalid, legitimate and illegitimate species, varieties, formae as well as herbarium names ${ }^{1}$. Reasons for this vast number of taxa probably reside in the imprecise, wide circumscription of this genus in literature, the strong morphological variability of most species and the occurrence of some species on a wide range of substrates. The members of Cladosporium is a dematiaceous fungi occurring on all kinds of living and dead leaves and stems of herbaceous and woody plants, as secondary invaders on necrotic leaf lesions caused by other fungi, are frequently isolated from air, soil, food stuffs, paint, textiles and other organic matters.

Reviews keys of Cladosporoid taxa on living plants were provided by a large number of worker from India and abroad. Some of them are : Amanelah, Beharvandi \& Zafari $^{2}$, Avasthi, Gautam \&Bhadauria ${ }^{3}$ Bensch et $a 1^{4}$., Braun $\&$ Hill $^{5}$, Braun \& Crous $^{6}$, Crous $^{7}$, Crous et al, ${ }^{8}$. Crous ${ }^{9}$ ,Das ${ }^{10}$,David \&David ${ }^{11}$,Dugan et al. ${ }^{12}$, Ellis $^{13}$, Ellis ${ }^{14}$, Heuchert, Braun \&Schubert ${ }^{15}$, He \& Zhanh ${ }^{16}$,Jang et $a l^{17}{ }, \operatorname{Kirk}^{18}$, Mułenko, Schubert \& Kozlowska ${ }^{19}$, Partridge \& MorganJones ${ }^{20}$, Schubert et al, ${ }^{21}$ Schubert \& Braun ${ }^{22}$,Seifert ,Nickerson \& Corlet $^{23}$ Schubert \& Braun ${ }^{24}$, Wirsel SGR \& RungeFrobose $^{25}$, Thomma, Van Esse \& Crous $^{26}$, Schubert et al ${ }^{27}$, Braun \& Schubert ${ }^{28}$, Zhang et $a l^{29}$, Sharma et $a l^{30}$, SandovalDenis et $a^{31}$, Subramania ${ }^{32}$, Kamal ${ }^{33}$ and Haldar ${ }^{34}$.

During working on the foliicolous fungi of Murshidabad district in the year 2016 of West Bengal the author had collected two members of Hyphomycetes growing on the living leaves of Clitoria ternatea L. (Fabaceae)and Hibiscus mutabilis

Corresponding Author:

Dinesh Haldar, Associate Professor, Department of Botany, Krishnath College, Berhampore, Murshidabad-742101, West Bengal, India. Email: haldar.dinesh85@gmail.com

ISSN: 2231-2196 (Print) ISSN: $0975-5241$ (Online)

Received: 27.01 .2019

Revised: 14.02.2019

Accepted: 27.02 .2019 
L.(Malvaceae). which on critical examination found to be two new species of the genus Cladosporium. Hence, these two species. Cladosporium clitoriae Haldar sp.nov. and Cladosporium murshidabadense Haldar sp.nov. have been created as new taxa (Myco Bank $\left.{ }^{35}\right)$.

The district of Murshidabad is located in the central part of the state of West Bengal under Presidency Division, lies between $23^{\circ} 43^{\prime}$ to $24^{\circ} 52^{\prime} \mathrm{N}$ latitude and $87^{\circ} 49^{\prime}$ to $88^{\circ} 44^{\prime} \mathrm{E}$ longitude and occupies an area of $5341 \mathrm{sq} \mathrm{km}$. The district is separated from the Maldah district by the river Ganga on its north. The eastern boundary of the district is formed by Bangladesh. It is bounded by the districts of Burdwan and Nadia on the south, the Birbhum district and the state of Jharkhand located in the western side. The river Bhagirathi flowing across the district divides it into almost two equal parts. The western part is known as Rarh which is substantially continuation of sub-vindhyan region. The soil of this district is primarily alluvial. The tract east to river is known as Bagri and is covered with recent alluvium consisting sandy clay. The elevation of the district is from $10 \mathrm{~m}$ to $50 \mathrm{~m}$ above MSL. Ganga and its tributaries such as Bhagirathi, Jalangi and Bhairab are the important rivers of the district. The district is oppressively having hot summer, short winter, high humidity and good rainfall during monsoon season. The average annual rainfall of the district is $1400 \mathrm{~mm}$.

\section{MATERIALS AND METHODS}

Specimens with typical disease symptoms of Cladosporoid fungi on living leaves were collected during field trips. The infected leaves were detached intact from the host plants and they were kept in polythene bags and processed by following standard techniques Castaneda ${ }^{85}$. Photographs of the infected spots on the host leaves were captured by Sony DSCHX200, camera and for the examination of fungal structure and spore morphology, the microscope slides were prepared in lacto-phenol cotton blue mixtures of the recognised species. Morphotaxonomic study of the associated fungi was done through the low and high magnification 100x400 of the compound microscope, (Olympus-CX21i FS1 Research Microscope) by using USB INSTA CMOS camera. The microphotographs were stored in electronic format JPEG. Holotypes being deposited at AMH, Agharkar Research Institute (ARI), Pune (MS), India and isotypes retained in the Departmental herbarium (KNC)for future reference.

\section{RESULTS}

\section{Cladosporium clitoriae Haldar sp.nov.(Fig.1)}

\section{Myco Bank MB 829285}

Incidence in winter, infection foliicolous inciting whitish, necrotic, spots amphigenous distinct on upper surface, numerous, subcircular to irregular, sometimes surrounded by grey margin, lesions occasionally developing shothole appearance, 1.5-2.5 in diam. caespituli epiphyllous, brown, mycelium immersed, superficial, smooth. stroma amphigenous, well developed, arising from the epidermal hairs of the host tissue, composed of thick walled isodiametric type of cells, light brown: conidiophores solitary to fasciculate, with 2-8 divergent stalks in a fascicle arising from the base of the stroma and rarely through the stomata, straight to curved, pale brown, septate, simple to branched, sometimes nodose with terminal and intercalary swelling, thick walled, smooth with distinct scars, after succession of conidia, apex sub acute to obtuse, average length 277.56$627.92 \mu \mathrm{m}$ and breadth-29.16 $\mu \mathrm{m}$.conidia solitary to catenate up to 3 in a chain, pale olivaceous, usually straight, rarely curved, cylindrical, ellipsoidal, thin walled, smooth to verruculose, up to 4 septate, often with distinct protuberant scar at both ends, average length 53.49-212.89 $\mu \mathrm{m}$ and breadth $29.16 \mu \mathrm{m}$.

Etymology: Referring to the genus of the host.

Habitat in folis vivis Clitoria ternatea L.(Fabaceae),Ring Road, Berhampore, Murshidabad, West Bengal, India, AMH 9847(Holotypus), KNC 142 (Isotypus). D.Haldar, 06.11.1016.

\section{Cladosporium murshidabadense sp.nov.(Fig.2)}

\section{MycoBank MB 829286}

Incidence in rainy season, spots formed on lamina, amphigenous, semi circular to circular, dark brown centre surrounded by blackish margin, sometimes no definite spots, only greyish discoloration without any boundary, $0.5-10 \mathrm{~mm}$ in diam,; caespituli amphigenous, vein limited, unevenly distributed over the spots, black; stroma present(23.60-297.87 $\mu \mathrm{m})$,occasionally only a few brownish spherical to gobular hyphal cells, substomatal; conidiophores amphigenous, solitary to fasciculate, in fascicles 2-7 stalks emerging the stomatal opening, straight to flexus, brown to pale brownish, simple or branched, thick walled, smooth, very often nodose, plurisepted (1-9 septa),septa distinct, often geniculate, often terminal vesicular swelling with distinct spore scar lying at the apex or by the side wall of the conidiophores, (average length $559.33-1124.60 \mu \mathrm{m})$ and breadth(40.79-48.02 $\mu \mathrm{m})$;conidia solitary to catenate, cylindrical, ellipsoidal, lemon shaped, oblong, pale brown, smooth, thick walled 0-3 septate, hilum distinct aat one end or both ends, average length,(53.26-137.97 $\mu \mathrm{m})$ and average breadth (25.81-54.88 $\mu \mathrm{m})$.

Specimen studied: On Hibiscus mutabilis L. (Malvaceae), Kossim Bazar, Berhampore, Murshidabad, West Bengal, India, AMH-9748(Holotypus), KNC 317(Isotypus), D. Haldar, 2 June, 2016. 
Etymology: Referring to the genus of the host.

No species of Cladosporium has yet been recorded and described on the hosts Clitoria ternatea L.(Fabaceae) and $\mathrm{Hi}$ biscus mutabilis L.(Malvaceae) and there is no record of this genus so far on other members of the family Fabaceae and Malvaceae respectively. So, the present fungus is described and illustrated here as a new taxon.

\section{DISCUSSION}

The fungi Cladosporium clitoriae Haldar and Cladosporium murshidabadense Haldar has been found to occur profusely during winter months to spring and early summer. The host plants Clitoria ternatea L. and Hibiscus mutabilis L. both are economically important. The roots of Clitoria ternatea L. is used as powerful cathartic and diuretic. Flowers yield a blue dye. Seeds contain a fixed oil. Both seeds and root-bark contain tannin. Purgative and leaves used as fodder. On the other hand Hiiscus mutabilis L. bark yields a strong fibre of inferior quality. Leaves used for cough, menorrhagia, dysuria and wounds caused by burns and scalds. Flowers given in pectoral and pulmonary complaints ${ }^{36}$.

\section{CONCLUSION}

Two new species of Cladosporium viz Cladosporium clitoriae Haldar and Cladosporium murshidabadense Haldar growing on two ornamental plants namely Clitoria ternatea L. and Hibiscus mutabilis L. They cause severe leaf infection of the host plants resulted which the growth of the plants become stunted. A pathologist should develop the control measures of the disease.

\section{ACKNOWLEDGEMENTS}

The author is thankful to the Principal, Krishnath College, Murshidabad, West Bengal for rendering help during the present work.. The author expresses his sincere gratitude to the Curator of AMH-ARI, Pune for depositing holotype of the specimens and providing the accession numbers. I wish to acknowledge the extended help of Dr. S. Bandyopadhyay, Assistant Professor and Head, Department of Botany, Krishnath College, Murshidabad for the identification of host plants. The author is also grateful to the Director, UGC, for financial support. Author acknowledges the immense help received from the scholars whose articles are cited and included in reference in the manuscript. The author is also grateful to authors/editors/publishers of all those articles, journals and books from where the literature for this article has been reviewed and discussed.

\section{REFERENCES}

1. Dugan, FM, K Schubert,\& U Braun. Check-list of Cladosporium names. Schlechtendalia, 2000;11 p. 1-103.

2. Amanelah Baharvandi, H., \& Zafari, D. Identification of Cladosporium delicatulum as a mycoparasite of Taphrina pruni. Archives of Phytopathology and Plant Protection, 2015; 48(8), 688-697.

3. Avasthi, S., Gautam, A., \& Bhadauria, R. First report of Cladosporium sphaerospermum causing leaf spot disease of Aloe vera in India. Journal of Crop Protection, 2016; 5(4), 649-654.

4. Bensch, K, Braun, U, Groenewald, JZ \& Crous, PW. The genus Cladosporium, Studies in Mycology, 2012; 72,(1), p. 1-401.

5. Braun U \& Hill CF. Some new micromycetes from New Zealand. Mycological Progress, 2002; 1 p. 19-30.

6. Braun U,\& Crous PW. Keys. Cladosporium and similar genera. pp. 897-901 In: The Genera of Hyphomycetes (Seifert K, Morgan-Jones G, Gams W, Kendrick B, editors., eds.) CBS Biodiversity Series, 9: p.1-997. 2011.

7. Crous, P. W. Common but different: The expanding realm of Cladosporium. Studies in Mycology, 2015;82, 23-74.

8. Crous P.W. Braun U. K. Schubert J \& Z. Groenewald. Delimiting Cladosporium from morphologically similar genera Mycology Volume, 2007;p 33-56.

9. Crous, PW. Mycosphaerella spp. and their anamorphs associated with leaf spot diseases of Eucalyptus, Mycologia Memoir, 21 p. 1-170.1998.

10. Das A.K.. Two new species of Cladosporium. Indian Phytopath, 2003; 56(2):164-167.

11. David, J.C. David. A contribution to the systematics of Cladosporium. Revision of the fungi previously referred to Heterosporium Mycological Papers, 1997;172 , p. 1-157.

12. Dugan FM, Braun U, Groenewald JZ, \& Crous PW. Morphological plasticity in Cladosporium sphaerospermum. Persoonia, 2008;21: 9-16.

13. Ellis MB. Dematiaceous hyphomycetes, Commonwealth Mycological Institute, Kew. 1971.

14. Ellis, MB. More dematiaceous hyphomycetes, Commonwealth Mycological Institute, Kew. 1976.

15. Heuchert B , Braun, U,\& K Schubert. Morphotaxonomic revision of fungicolous Cladosporium species (hyphomycetes). Schlechtendalia, 2005.

16. He YH, \& Zhang ZY. Taxonomy of Cladosporium in China. XXVII. Mycosystema, 2002; 21(1): 21-22.

17. Jang, Y., Lee, Y. M., Kim, G. H., \& Kim, J. J. Two species of Cladosporium associated with wood discoloration in Korea. Mycotaxon, 2013; 124(1), 21-29.

18. Kirk PM. Authors of fungal names. CABI Bioscience,2003 www. indexfungorum.org/AuthorsofFungalNames.htm.

19. Mułenko W, Schubert K, Kozlowska. M Cladosporium galii sp. nov. on Galium odoratum from Poland. Mycotaxon, 2004; 90(2): 271-274.

20. Partridge EC, \& Morgan-Jones G. Notes on hyphomycetes. XC. Fusicladosporium, a new genus for Cladosporium-like anamorphs of Venturia, and the pecan scab-inducing fungus. Mycotaxon, 2003; 85: 357-370.

21. Schubert, K, U Braun, W Mulenko, Konstanze Bensch Westerdijk, Groenewald Westerdijk. Taxonomic revision of the genus Cladosporium s. lat. 5. Validations and descriptions of new species. Schlechtendalia, 2006.14 p 55-83.

22. Schubert, K, Braun, U. Taxonomic revision of Cladosporium s. lat. 1. Species to Fusicladium, Parastenella, Passalora, Pseudocercospora and Stenella. Mycological Progress, 2005. 
23. Seifert, KA, NL Nickerson,\& M Corlet.t Devriesia, A new hyphomycete genus to accommodate heat-resistant, Cladosporium-like fungi Journal of Botany, 2004. NRC Research Press.

24. Schubert, K,\& Braun U, 2007.Taxonomic revision of the genus Cladosporium s. lat. 6. New species, reallocations to and synonyms of Cercospora, Fusicladium, Passalora, Septonema and Stenella. Nova Hedwigia.

25. Wirsel, SGR, \& C Runge-Froböse.. Four or more species of Cladosporium sympatrically colonize Phragmites australis Fungal Genetics. 2002.

26. Thomma, BPHJ, HP Van Esse, \& Crous PW. Cladosporium fulvum (syn. Passalora fulva), a highly specialized plant pathogen as a model for functional studies on plant pathogenic Mycosphaerellaceae, Molecular plant 2005.

27. Schubert, K.A Greslebin, JZ Groenewald,\& Crous PW. New foliicolous species of Cladosporium from South America Persoonia, 2009.

28. Braun, U, \& K Schubert Taxonomic revision of the genus Cladosporium s. lat. 7. Descriptions of new species. a new combination and further new data. Schlechtendalia,2013.

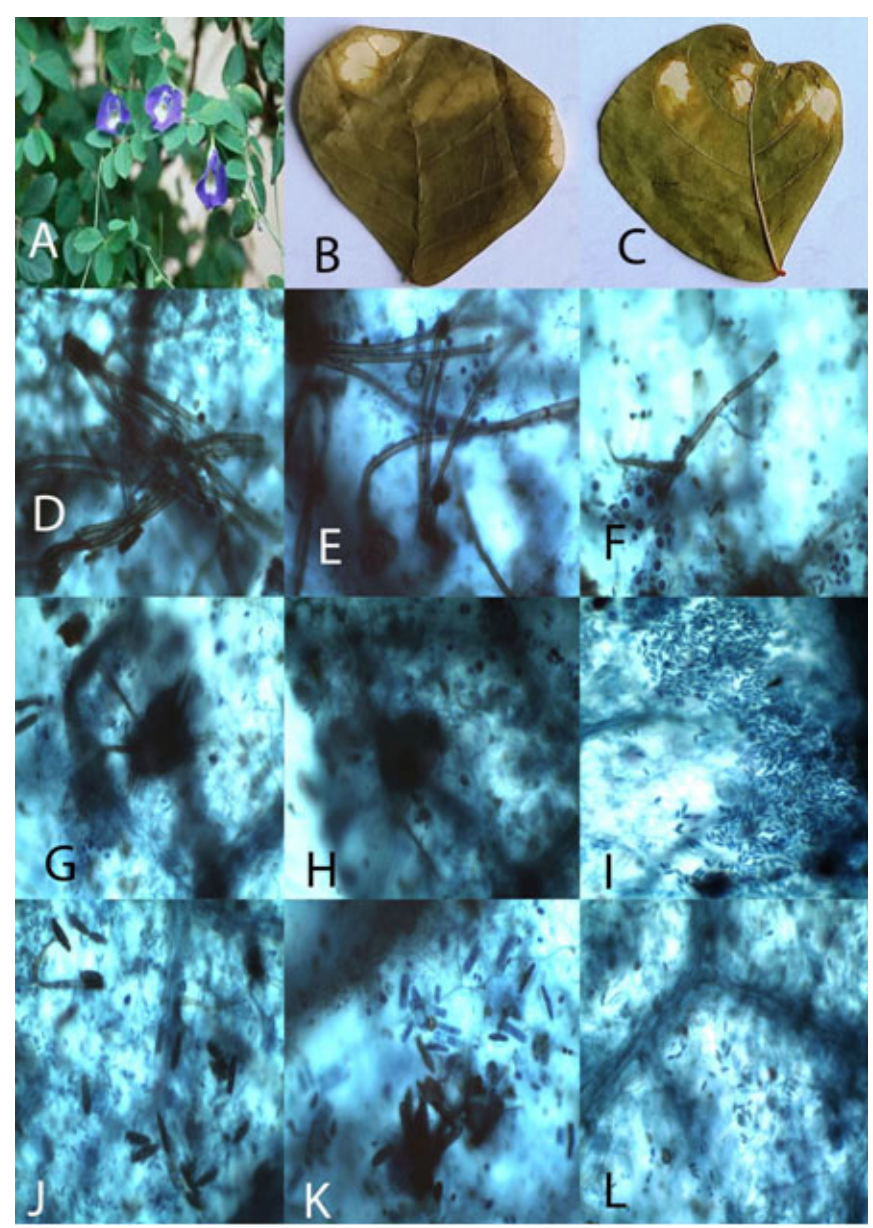

Figure 1: Cladosporium clitoriae on Clitoria terternatea. AHost plant.B-C: Leaf spots.D-F:Conidiophores.G-H :Strpma:IL:Conidia: Scale bars $=20 \mathrm{~mm}$.
29. Zhang ZY, Liu YL, Zhang T, Li TF, Wang G, Zhang H,\& He YH, H.. Flora Fungorum Sinicorum, 2003. 14, Cladosporium, Fusicladium, Pyricularia.

30. Sharma,C.D.,Gadpandey,K.K.,Firdousi,S.A.,Rai,A.N \& K.M Three new species of Cladosporium from Madhya Pradesh,India. Indian Phytopath, 1998.51:152-160.

31. Sandoval-Denis, M., Gené, J., Sutton, D. A., Wiederhold, N. P., Cano-Lira, J. F., \& Guarro, J. New species of Cladosporium associated with human and animal infections. Persoonia,2016. Molecular Phylogeny and Evolution of Fungi, 36, 281.

32. Subramanian, C.V. Hyphomycetes, Taxonomy and Biology Academic Press, New York,1983.p 502.

33. Kamal. Cercosporoid fungi of India. Bishen Singh Mahendra Pal Singh, Deharadun India.ISBN:978-81-211-0753-2, p. 351.2010.

34. Haldar, D. Two new Dematiaceous fungi from West Bengsl, India, Int J Cur Res Rev, 2017; 9(6)2017.

35. Mycobank 2019.Mycobank (Fungal databases nomenclature and species banks), accessed January4,2019,http://www.mycobank.org

36. The useful plants of India. Publication \& Information Directorate, CSIR,New Delh, 1986.

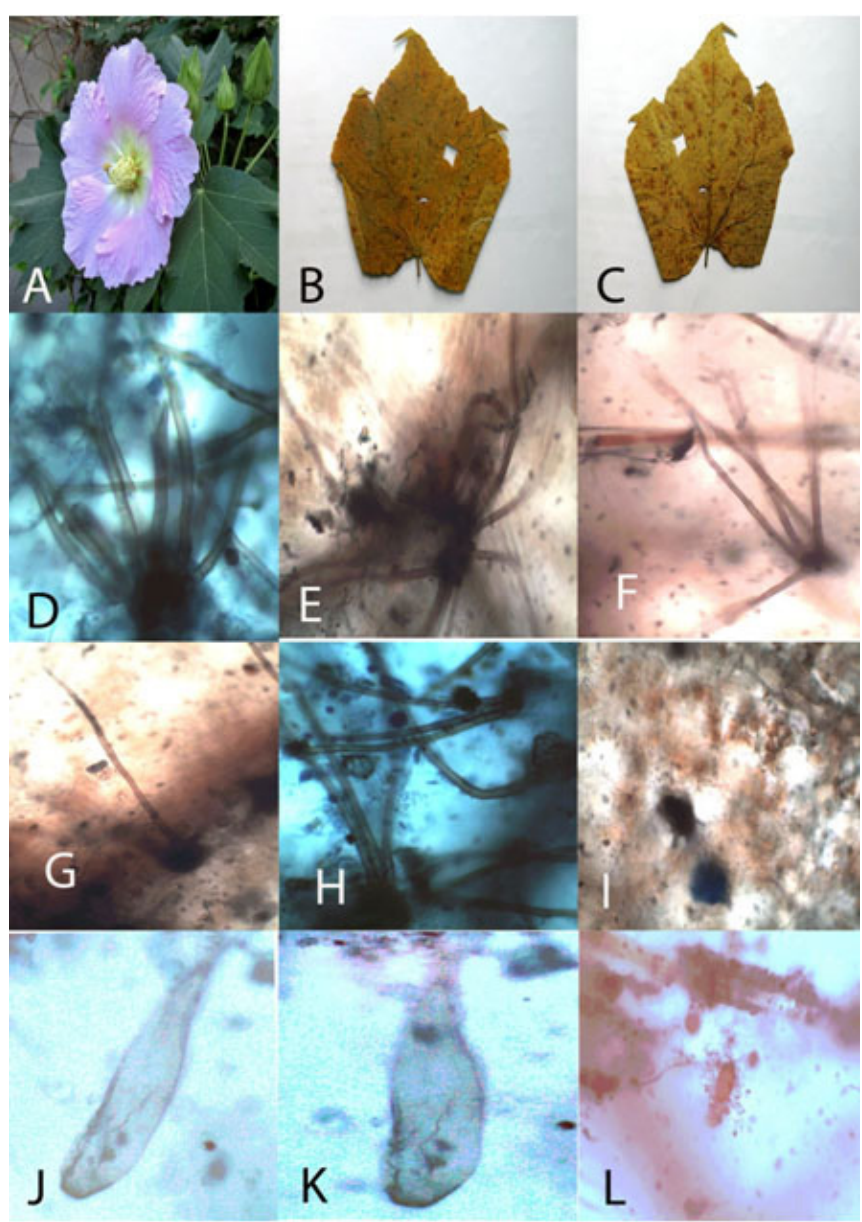

Figure 2: Cladosporium murshidabadense on Hibiscus mutabilis. A-Host plant. B-C: Leaf spots.D-H:Conidiophores.G-H: Strpma:I.J-L:Conidia: Scale bars $=20 \mathrm{~mm}$. 